\title{
Induction of Interleukin-6 by Depolarization of Neurons
}

\author{
Svea Sallmann, ${ }^{1}$ Eric Jüttler, ${ }^{1}$ Simone Prinz, ${ }^{1}$ Nicole Petersen, ${ }^{1}$ Udo Knopf, ${ }^{2}$ Thomas Weiser, ${ }^{3}$ and \\ Markus Schwaninger ${ }^{1}$

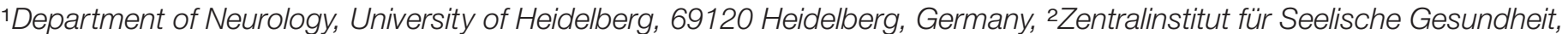 \\ 68159 Mannheim, Germany, and 3BBoehringer Ingelheim Pharma KG, 55126 Ingelheim, Germany
}

Interleukin-6 (IL-6) has neuromodulatory and neuroprotective effects in vivo. It is expressed in glial cells and neurons both under physiological conditions and in various neurological diseases. Although the expression of IL-6 in glia has been intensely investigated, little is known about the regulation of IL-6 production by neurons. Therefore, we investigated the regulation of IL- 6 expression in neurons. Membrane depolarization raised IL-6 mRNA accumulation in primary cortical cells and the PC-12 cell line. In vivo, IL-6 mRNA in the brain increased significantly after epileptic seizures. To investigate IL- 6 gene transcription, PC-12 cells were transfected with reporter gene constructs containing the human IL-6 promoter. Membrane depolarization raised IL-6 transcription twofold to fourfold. This increase could be blocked by lowering extracellular $\mathrm{Ca}^{2+}$ levels or by inhibiting L-type $\mathrm{Ca}^{2+}$ channels or $\mathrm{Ca}^{2+} /$ calmodulin-dependent protein kinases. Internal mutations in various elements of the IL-6 promoter revealed the glucocorticoid response element (GRE) 2 to be a depolarizationresponsive element. Although the GRE2 bound the glucocorticoid receptor (GR) and was stimulated by dexamethasone, the GR was not responsible for the effect of membrane depolarization because a consensus GRE did not mediate stimulation by membrane depolarization. Instead, another yet undefined factor that binds to the IL-6 GRE2 may mediate the response to membrane depolarization. These data demonstrate that the expression of IL-6 in neurons is regulated by membrane depolarization and suggest a novel $\mathrm{Ca}^{2+}$-responsive promoter element. Through this mechanism, IL-6 may function as a neuromodulator induced by neuronal activity.

Key words: IL-6; membrane depolarization; gene transcription; neurons; cytokine; calcium
The cytokine interleukin-6 (IL-6) is a systemic mediator of the acute phase response in infection. IL- 6 induces the expression of acute phase proteins in the liver (Gauldie et al., 1987), the differentiation of B lymphocytes (Kopf et al., 1994), and protein breakdown in muscle (Goodman, 1994). It also coordinates the neural component of the acute phase reaction by inducing fever and sickness behavior and activating the hypothalamic-pituitaryadrenal axis (Chai et al., 1996; Kozak et al., 1997; Ruzek et al., 1997). Glial cells express IL-6 when stimulated by virus, cytokines, or various neuromodulators (Frei et al., 1989; Benveniste, 1992; Schwaninger et al., 1997, 1999). An increased expression of IL-6 in the brain has been described in various forms of meningitis or encephalitis, as well as in models of systemic sepsis (Gadient and Otten, 1997).

Like the resident immunocompetent cells such as astrocytes or microglia, neurons also have been shown to be a source of IL-6 both in vivo and in vitro. Some authors have even detected IL-6 in neurons under normal physiological conditions. (Schöbitz et al., 1993; Gadient and Otten, 1994; März et al., 1998). However, there is a pronounced increase in the expression of neuronal IL-6 in cerebral ischemia and after axotomy (Murphy et al., 1995; Suzuki et al., 1999a,b). IL-6 expression in neurons contributes to the activation of glial cells (Fattori et al., 1995; Klein et al., 1997), protects neighboring neurons (Hama et al., 1991; Yamada and Hatanaka, 1994; Matsuda et al., 1996; Loddick et al., 1998), and supports the regeneration of peripheral nerves after a crush lesion (Zhong et al., 1999). However, chronic exposure of neurons to IL-6 increases $\mathrm{Ca}^{2+}$ influx in response to NMDA and causes neurodegenerative changes (Campbell et al., 1993; Qiu et al., 1998).

Received May 2, 2000; revised Aug. 31, 2000; accepted Sept. 15, 2000.

This study was supported by a grant from the Deutsche Forschungsgemeinschaft to M.S. We greatly appreciate the generous gift of KN-93 from H. Hidaka (Nagoya, Japan), the help of B. Storch-Hagenlocher (Heidelberg, Germany) with the preparation of primary cells, and the excellent technical assistance of G. Mengeling (Boehringer Ingelheim Pharma KG).

Correspondence should be addressed to Dr. Markus Schwaninger, Department of Neurology, University of Heidelberg, Im Neuenheimer Feld 400, 69120 Heidelberg, Germany. E-mail: markus.schwaninger@med.uni-heidelberg.de.

Copyright (C) 2000 Society for Neuroscience 0270-6474/00/208637-06\$15.00/0
Although numerous studies have been conducted on the regulation of IL- 6 expression in glial cells, little is known about the regulation of IL- 6 in neurons. Only interleukin- $1 \beta$, tumor necrosis factor- $\alpha$, and a yet undefined factor from mast cells have been reported to stimulate the expression of IL-6 in cortical and sensory neurons (Ringheim et al., 1995; Murphy et al., 1999). Here, we report study results indicating that membrane depolarization induces IL- 6 expression in neurons and further investigate the underlying molecular mechanism.

\section{MATERIALS AND METHODS}

Cell culture and transfection. Cortical neurons were prepared from embryonic day 14 (E14) rats. They were cultured in Neurobasal medium supplemented with B27 (Life Technologies, Karlsruhe, Germany), 25 mm glucose, $0.5 \mathrm{~mm}$ L-glutamine, penicillin (50 IU $/ \mathrm{ml})$, and streptomycin (50 $\mu \mathrm{g} / \mathrm{ml})$. Cerebellar granule cells were prepared from postnatal day 7 (P7) mice. Cells were plated on poly-L-lysine precoated 24-well plates (Sarstedt, Nümbrecht, Germany). Cells were seeded at a density of 400,000 cells per well in basal modified Eagle's (Life Technologies) medium supplemented with $10 \%$ fetal calf serum (PAA Laboratories, Cölbe, Germany), $20 \mathrm{~mm}$ $\mathrm{KCl}$, penicillin $(50 \mathrm{IU} / \mathrm{ml})$, and streptomycin $(50 \mu \mathrm{g} / \mathrm{ml})$. On the first day in vitro, cells were transfected with Transfast as described previously (Ango et al., 1999). After $48 \mathrm{hr}$ in culture, cytosine- $\beta$-D-arabinofuranoside (10 $\mu \mathrm{M})$ was added. Cerebellar granule cells were stimulated on the fourth day in culture. PC-12 cells were obtained from DSMZ (Braunschweig, Germany) and were cultured in RPMI containing $10 \%$ fetal calf serum, penicillin $(50 \mathrm{IU} / \mathrm{ml})$, and streptomycin $(50 \mu \mathrm{g} / \mathrm{ml})$. Plates were coated with collagen $(60 \mu \mathrm{g} / \mathrm{ml})$ for $1 \mathrm{hr}$. Two days before transfection, the cells were transferred to 24 -well plates $(200 \mu \mathrm{l} /$ well $)$. For transfection, $6 \mu \mathrm{l}$ of Transfast $(0.4 \mathrm{mg} / \mathrm{ml}$; Promega, Madison, W I), $1 \mu \mathrm{g}$ of the first reporter, and $0.05 \mu \mathrm{g}$ of pRLSV40 (Promega) as a second reporter were used according to the instructions of the manufacturer. Primary astrocytes were cultured and transfected as described previously (Schwaninger et al., 1999). After incubation for $42 \mathrm{hr}$ in full medium, PC-12 cells and primary astrocytes were stimulated for $6 \mathrm{hr}$ and harvested immediately afterward. The activity of firefly luciferase was measured as described previously (Schwaninger et al., 1993b); for Renilla luciferase, the Dual Luciferase Reporter Assay (Promega) was used. Luciferase vectors containing various mutations within the IL-6 promoter have also been described previously (Schwaninger et al., 1999). For the vectors 4xcGREIL6Luc, 4xGRE2IL6Luc, and 4xmGRE2IL6Luc, a truncated form of the human IL-6 promoter $(-179 /+8)$ was subcloned into the XhoI and BglII sites of pXP2 (Nordeen, 1988). Then, four copies of the following oligonucleotides were cloned in front of the truncated IL-6 promoter: GRE2, 5'-CAG TTC AGA ACA TCT TTG GTT-3'; mGRE2, 5'-CAG TTC 
Primary cortical cells

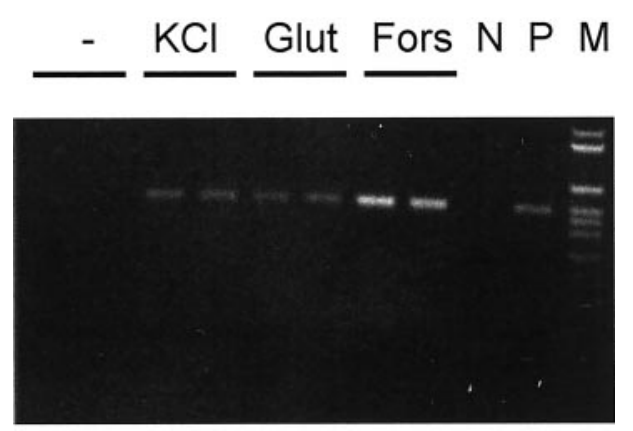

PC-12

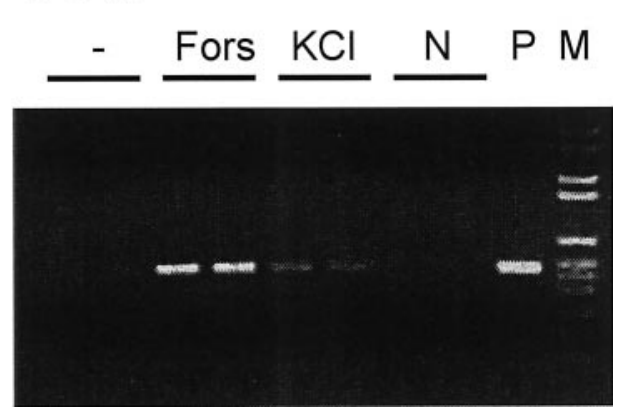

Figure 1. Membrane depolarization stimulates the mRNA accumulation of IL-6 in primary cortical cells and the neuron-like cell line PC-12. Neurons were stimulated for $6 \mathrm{hr}$ and PC-12 cells for $4 \mathrm{hr}$ by elevating the extracellular $\mathrm{KCl}$ concentration to $45 \mathrm{~mm}$, by $100 \mu \mathrm{M}$ glutamate (Glut) or by $10 \mu \mathrm{M}$ forskolin (Fors). N, Negative PCR control; P, positive control; M, marker. The product of the semiquantitative PCR is 496 bp in size. Amplification of $\beta$-actin mRNA showed no difference between treatment groups.

AGC TGA TCT TTG GTT-3'; and cGRE, 5'-AG AAC AGA GTG TTC T- $3^{\prime}$. All constructs were confirmed by sequencing.

Semiquantitative IL-6 reverse transcription-PCR. RNA was extracted from cells and tissues with the RNA clean kit (Angewandte Gentechnologie Systeme, Heidelberg, Germany) according to the instructions of manufacturer. Total RNA $(10 \mu \mathrm{g})$ was transcribed with MMLV reverse transcriptase and random hexamers. For PCR of rat IL-6 cDNA, the following primers were used: sense, CTT CCA GCC ATG TGC CTT CT; and antisense, GAG AGC ATT GGA AGT TGG GG. PCR was performed according to the following protocol: $10 \mathrm{~min}$ at $94^{\circ} \mathrm{C}, 30 \mathrm{sec}$ at $94^{\circ} \mathrm{C}, 40 \mathrm{sec}$ at $56^{\circ} \mathrm{C}$, and $45 \mathrm{sec}$ at $72^{\circ} \mathrm{C}$. The amplified products were subjected to gel electrophoresis $(1.5 \%$ agarose) (Fig. 1$)$.

Quantitative IL-6 reverse transcription-PCR. RNA extraction and reverse transcription were performed as described above. For the quantitative real-time PCR of IL- 6 from mouse tissues, the following primers were used: IL-6 sense, AAA GAG TTG TGC AAT GGC AAT TCT; IL-6 antisense, AAG TGC ATC ATC GTT GTT CAT ACA; glyceraldehyde3-phosphate dehydrogenase (GAPDH) sense, CAT TGT GGA AGG GCT CAT GA; GAPDH antisense, TCT TCT GGG TGG CAG TGA TG; cyclophilin sense, AGG TCC TGG CAT CTT GTC CAT; and cyclophilin antisense, GAA CCG TTT GTG TTT GGT CCA. For PCR of IL-6 from rat cortical neurons, the following primers were used: IL-6 sense, AAA GAG TTG TGC AAT GGC AAT TCT; IL-6 antisense, CAG TGC ATC ATC GCT GTT CAT ACA; GAPDH sense, CAT CGT GGA AGG GCT CAT GA; and GAPDH antisense, TCT TCT GAG TGG CAG TGA TG. PCR was performed according to the following protocol: $10 \mathrm{~min}$ at $95^{\circ} \mathrm{C}$, $15 \mathrm{sec}$ at $95^{\circ} \mathrm{C}$, and $1 \mathrm{~min}$ at $60^{\circ} \mathrm{C}(40$ cycles). Amplification was quantified with the Gene Amp 5700 sequence detector and the SYBR Green kit (PE Diagnostik, Weiterstadt, Germany). A linear concentration-response curve was established by diluting pooled samples. The quantitation results for IL-6 PCR were normalized to those for GAPDH or cyclophilin PCR in individual samples. The purity of the amplified product was checked by the dissociation curve and gel electrophoresis of selected samples. Furthermore, the identity of the product was verified by sequencing after subcloning into the vector pCR II-TOPO (Invitrogen, Groningen, The Netherlands).

Maximum electroshock test. Male mice (OF1; IFFA Credo, Reims,
France) weighing $\sim 21-32$ gm were used in the experiments. The animals were kept in groups of 10 , without individual identification, in Makrolon cages type III bedded with soft wood granulate. They had access to a standard pellet diet and tap water ad libitum in an air-conditioned animal room $\left(\sim 25^{\circ} \mathrm{C}\right)$. The maximum electroshock test (Toman et al., 1946) was performed as follows: an electroshock $(20 \mathrm{~mA}, 50 \mathrm{~Hz}, 200$ msec) was applied to the mouse via saline-moistened eye electrodes (Rodent shocker Type 221; Hugo Sachs Elektronik, March-Hugstetten, Germany). This had been determined in previous control experiments to be a supramaximal stimulus, resulting in a fully developed tonic convulsion in $100 \%$ of the mice.

Gel shift assays. PC- 12 cells on $6 \mathrm{~cm}$ plates were stimulated for $2 \mathrm{hr}$ if indicated. Nuclear extracts were prepared as described previously (Schreiber et al., 1989). Double-stranded oligonucleotides with 5'-GATC overhangs and the following sequence from the human IL-6 promoter were annealed and labeled by a fill-in reaction with $\left[\alpha-{ }^{32} \mathrm{P}\right] \mathrm{dCTP}$ and Klenow enzyme: GRE2, GAT CCA GTT CAG AAC ATC TTT GGT TA. Labeled oligonucleotide and nuclear extract were incubated on ice for $15 \mathrm{~min}$ in a buffer containing $20 \mathrm{~mm}$ HEPES, pH 7.9, $60 \mathrm{~mm} \mathrm{KCl}, 5 \mathrm{~mm} \mathrm{MgCl} 2,0.05$ $\mu \mathrm{g} / \mu \mathrm{l}$ poly(dI-dC), $5 \mu \mathrm{g} / \mu \mathrm{l}$ bovine serum albumin, $10 \%$ glycerol, and $2 \mathrm{~mm}$ dithiothreitol (total volume, $20 \mu \mathrm{l}$ ). When recombinant glucocorticoid receptor (GR) (Affinity BioReagents, Grünberg, Germany) was used instead of nuclear extracts, the poly( $\mathrm{dI}-\mathrm{dC})$ concentration was reduced to 5 $\mathrm{ng} / \mu \mathrm{l}$. For competition, the following double-stranded oligonucleotides were used: mGRE2 (mutated sequence from the human IL-6 promoter), 5'-GAT CCA GTT CAG CTG ATC TTT GGT TA-3'; TYR-GRE (sequence from the human tyrosine aminotransferase promoter), $5^{\prime}$-GAT CTA GGC TGT ACA GGA TGT TCT GCC TAG-3'; and $\kappa \mathrm{B}$ (sequence from the $\kappa$ B promoter), $5^{\prime}$-GAT CCA GAG GGG ACT TTC CGA GA-3'.

\section{RESULTS}

\section{Expression of IL-6 is induced by membrane depolarization in neuronal cells}

Primary cortical neurons in cell culture were stimulated by increasing the extracellular potassium concentration to $45 \mathrm{mmol} / \mathrm{l}$. This treatment depolarizes membranes whose resting potential depends on the potassium permeability. The accumulation of IL-6 mRNA determined by reverse transcription (RT)-PCR was reproducibly elevated by membrane depolarization, although the cAMP agonist forskolin was more efficient (Fig. 1A). Quantification of IL-6 mRNA with real-time PCR revealed a $9.7 \pm 5$.4-fold induction $(n=5 ; p<0.05)$. Membrane depolarization by elevated potassium concentrations also stimulated the mRNA accumulation of IL-6 in the neuron-like cell line PC-12 (Fig. $1 B$ ). To evaluate whether the IL-6 expression is also controlled in vivo by membrane depolarization, we used the maximal electroshock model in mice. IL-6 mRNA was measured $6 \mathrm{hr}$ after the shock by quantitative RT-PCR. In the brains of electroshocked mice, IL-6 mRNA was significantly elevated. The calculated induction varied slightly with the housekeeping gene that was used for normalization. If IL-6 RT-PCR was normalized to the GAPDH PCR product, the electroshock increased IL- 6 mRNA to $158.0 \pm 28.1$ versus $100.0 \pm 3.9 \%$ in untreated animals $(n=8 ; p<0.05)$. Normalization to the cyclophilin PCR product resulted in an induction of $234.2 \pm 61.7$ versus $100.0 \pm 12.5 \%$ in untreated controls $(n=8 ; p<0.05)$.

As for other cytokines, the expression of IL-6 is regulated mainly at the level of gene transcription. IL- 6 gene transcription was investigated by transfecting PC-12 cells with a reporter gene construct containing the coding sequence of luciferase under transcriptional control of the human IL-6 promoter $(-1179 /+9)$. Membrane depolarization enhanced IL- 6 gene transcription twofold to fourfold (Fig. 2). Also in cerebellar granule cells, elevation of the extracellular potassium concentration from 25 to $65 \mathrm{~mm}$ stimulated IL-6 gene transcription (Fig. 3C)

\section{Induction of IL- 6 by membrane depolarization depends on $\mathrm{Ca}^{2+}$ influx and $\mathrm{Ca}^{2+} /$ calmodulin- dependent protein kinases}

Reducing the extracellular $\mathrm{Ca}^{2+}$ concentration by the chelator EGTA blocked the stimulatory effect of membrane depolarization on IL-6 gene transcription in PC-12 cells (Fig. $2 A$ ). This indicates that an influx of $\mathrm{Ca}^{2+}$ mediates the effect. Like primary neurons, PC-12 cells express voltage-dependent $\mathrm{Ca}^{2+}$ channels of the L-type. Because these high-conduction ion channels have been implicated in the regulation of gene transcription (Sheng et al., 
A
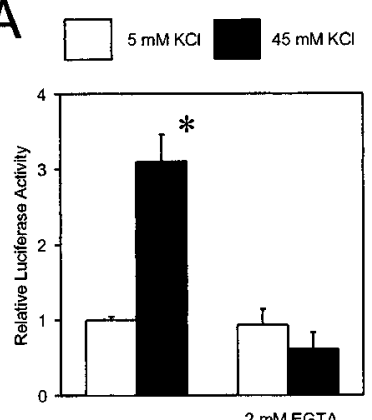

C

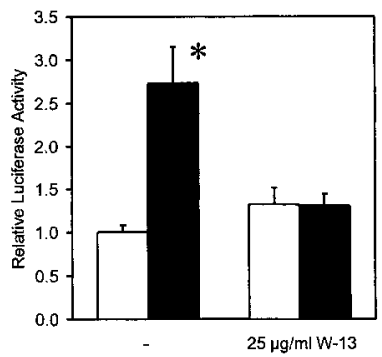

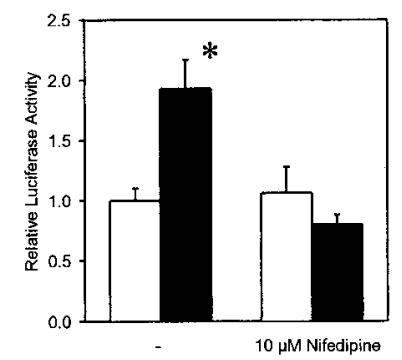

B

D

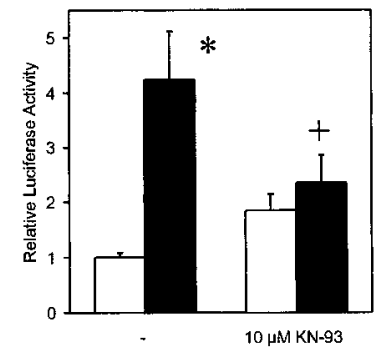

Figure 2. Stimulation of IL-6 gene transcription by membrane depolarization depends on $\mathrm{Ca}^{2+}$ influx and activation of CaM-dependent protein kinases. PC-12 cells were transfected with a reporter gene construct containing the luciferase sequence as reporter and the human IL-6 promoter $(-1179 /+9)$. Cells were stimulated by $45 \mathrm{mM} \mathrm{KCl}$ for $6 \mathrm{hr}$. Inhibitors were added $1 \mathrm{hr}$ before stimulation. Data are mean \pm SEM values of three to four independent experiments, each done in duplicate. ${ }^{*} p<0.01$ compared with untreated control. $+p<0.05$ compared with cells stimulated with 45 $\mathrm{mM} \mathrm{KCl}$.

1990), we used nifedipine, a selective L-type channel blocker, to test whether they are involved here as well. Indeed, nifedipine (10 $\mu \mathrm{M})$ abrogated the stimulation of IL- 6 gene transcription by membrane depolarization (Fig. $2 B$ ). In cerebellar granule cells, IL-6 gene transcription was induced $1.6 \pm 0.2$-fold $(n=9 ; p<0.05)$ by elevation of the potassium concentration to $65 \mathrm{~mm}$; addition of 10 $\mu \mathrm{M}$ nifedipine blocked this induction $(0.9 \pm 0.2$-fold of control; $n=$ 12). The effect of membrane depolarization in PC-12 cells was also inhibited by the calmodulin antagonist W-13 (20 $\mu \mathrm{M})$ (Fig. $2 C$ ) or by $\mathrm{KN}-93(10 \mu \mathrm{M})$, an inhibitor of $\mathrm{Ca}^{2+} /$ calmodulin-dependent protein kinases (Fig. 2D). Although FK506 (10 nM to $10 \mu \mathrm{M})$ stimulated luciferase expression, this effect was obviously not attributable to inhibition of calcineurin because rapamycin and cyclosporin A also stimulated luciferase expression, and the effects of rapamycin and FK506 were additive (data not shown). These data suggests that membrane depolarization induces IL- 6 gene transcription in neuron-like cells by an influx of $\mathrm{Ca}^{2+}$ through voltagedependent $\mathrm{Ca}^{2+}$ channels of the L-type and secondary activation of $\mathrm{Ca}^{2+} /$ calmodulin-dependent protein kinases.

\section{Mapping of a new $\mathrm{Ca}^{2+}$-responsive element in the IL-6 promoter}

Several stimulus-responsive elements have been described in the IL-6 promoter (Fig. 3A) (Sehgal, 1992). Among these, the CAAT box, the cAMP response element (CRE), and the binding sites for activation protein 1 (AP1) and nuclear factor $\kappa \mathrm{B}(\mathrm{NF}-\kappa \mathrm{B})$ have been shown to mediate the $\mathrm{Ca}^{2+}$ responsiveness in the context of other promoters (Sheng et al., 1990; Wegner et al., 1992; Frantz et al., 1994). To characterize the $\mathrm{Ca}^{2+}$-responsive promoter element in the neuron-like PC-12 cells, we transfected the cells with reporter gene constructs containing internal mutations in various elements. None of the mutations in the candidate elements, i.e., the $\mathrm{CRE}$, the CAAT box, or the binding sites for NF- $\kappa \mathrm{B}$ and AP-1, had

any significant effect on the stimulation by membrane depolarization and $\mathrm{Ca}^{2+}$ influx (Fig. 3B). However, an internal mutation within the glucocorticoid response element (GRE) 2 clearly diminished the depolarization-induced IL- 6 transcription. Mutation of the GRE2 also reduced the effect of membrane depolarization in cerebellar granule cells (Fig. $3 C$ ). In contrast, the same mutation in the GRE2 had no effect on the stimulation of IL-6 transcription through mobilization of intracellular $\mathrm{Ca}^{2+}$ by thapsigargin in astrocytes (Fig. 3D). A mutation in the GRE1 did not affect the induction of IL-6 transcription by membrane depolarization in PC-12 cells (Fig. $3 B$ ).

The GRE1 and GRE2 in the IL-6 promoter have been described as homologies to the consensus glucocorticoid element (Tanabe et al., 1988) but have not yet been functionally characterized. Indeed, gel shift assays demonstrated that recombinant human glucocorticoid receptor (rGR) binds to the GRE2 of the human IL-6 promoter (Fig. 4). rGR binding to the GRE2 of the IL-6 promoter was competed by an excess of a well characterized GRE from the tyrosine aminotransferase promoter (TYR GRE). Conversely, the IL-6 GRE2 also competed for the TYR GRE binding to rGR (data not shown). Although neurons and PC-12 cells are known to express GRs (Rozansky et al., 1994), we were unable to detect a reproducible binding activity that corresponded to the $\mathrm{GR}$ in nuclear extracts from PC-12 cells using gel shift assays.

IL-6 expression is inhibited by glucocorticoids; however, the underlying mechanism does not involve the GRE1 or GRE2 (Ray et al., 1990; Amano et al., 1993). In contrast, the transcription that was directed by four copies of the IL-6 GRE2 was enhanced by the glucocorticoid dexamethasone. The stimulation was sensitive to a mutation in the GRE2, but a consensus GRE mediated a more pronounced stimulation of gene transcription by dexamethasone (Fig. 5). Transcription directed through the GRE2 was also stimulated by membrane depolarization, whereas a mutation in the GRE2 abolished the effect of membrane depolarization. However, transcription mediated by the consensus GRE was not stimulated by membrane depolarization (Fig. 5), demonstrating that binding of the GR alone is not sufficient to stimulate gene transcription by membrane depolarization. This view was further supported by the effect of the anti-glucocorticoid RU468 that did not interfere with stimulation of IL-6 transcription by depolarization (data not shown). Using gel shift assays, we found a factor in nuclear extracts of PC-12 cells that migrated faster than rGR (Fig. 6). Binding of this factor was reduced by an excess of the wild-type GRE2, whereas the mutated GRE2 or an unrelated oligonucleotide had no effect. The identity of the factor is unknown at present.

\section{DISCUSSION}

The cytokine IL- 6 has been identified as an important mediator of the immune system, and it has also become clear that IL-6 coordinates the nervous component of the acute phase response and the activation of immunocompetent glia within the brain. In this function, IL-6 is expressed by glial cells. However, expression of IL-6 is not limited to glia but has also been detected in neurons by several authors (Schöbitz et al., 1993; Gadient and Otten, 1994; März et al., 1998). Previously, the neuronal expression was only known to be regulated by other cytokines, such as tumor necrosis factor $\alpha$ or IL-1 $\beta$ (Ringheim et al., 1995). Our data suggest, however, that membrane depolarization and the neuronal activity itself may induce IL-6 in neurons.

Pharmacological characterization indicated that $\mathrm{Ca}^{2+}$ influx through voltage-dependent $\mathrm{Ca}^{2+}$ channels of the L-type mediates the effect of membrane depolarization on IL- 6 gene transcription. The effect of KN-93 further suggested that $\mathrm{Ca}^{2+} /$ calmodulindependent protein kinases are involved. Elevating cytosolic $\mathrm{Ca}^{2+}$ concentrations has been reported to stimulate the transcription of the IL-6 gene in macrophages and glia (Bost and Mason, 1995; Schwaninger et al., 1999); however, in these paradigms, $\mathrm{Ca}^{2+}$ is mobilized from intracellular pools and activates other signaling pathways involving protein kinase $\mathrm{C}$ and calcineurin (Burd et al., 1989). $\mathrm{Ca}^{2+}$ influx through the high-conductance L-type channel 


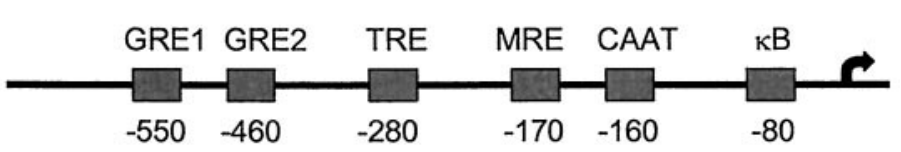

B

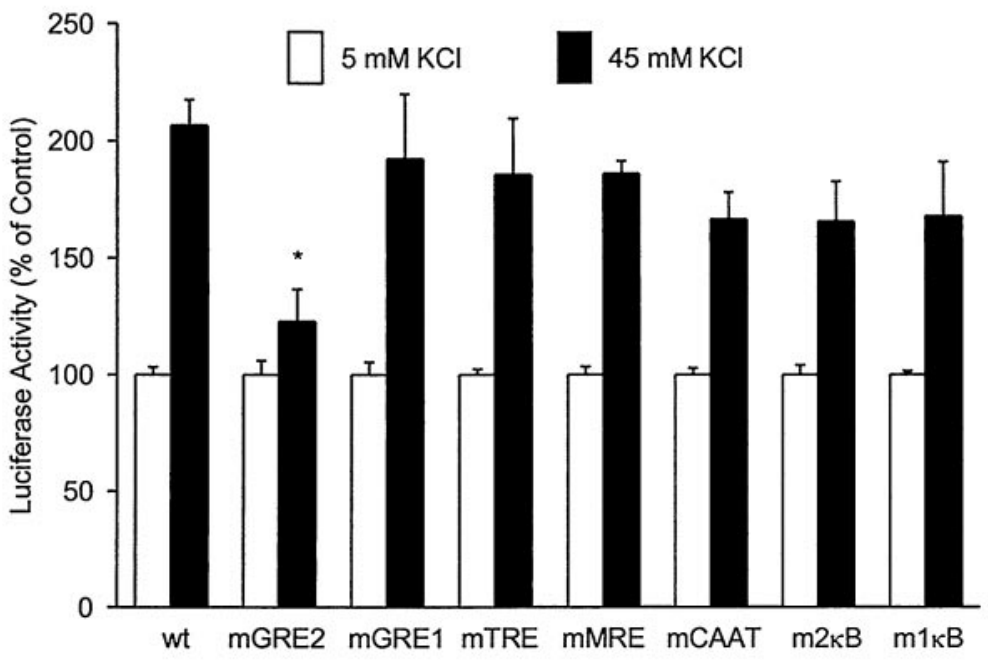

Figure 3. Stimulation of IL-6 gene transcription by membrane depolarization is mediated by the GRE2 in the IL-6 promoter. $A$, Scheme of the human IL-6 promoter. $B$, PC- 12 cells were transfected with reporter gene constructs containing mutations in the indicated promoter elements. Basal luciferase expression was affected by the mutations as follows [percent of wild-type $(w t)$ expression]: wt, $100.0 \pm 15.9 ;$ mGRE2, $77.0 \pm 42.9$; mGRE1, $11.1 \pm 1.9$; mutated TPA response element (mTRE), $74.6 \pm 16.9$; mutated multiple response element ( $m M R E)$, $76.5 \pm 34.8$; mCAAT, $78.1 \pm 35.6 ; \mathrm{m} 2 \kappa \mathrm{B}, 51.4 \pm 17.8 ; \mathrm{m} 2 \kappa \mathrm{B}$, $24.0 \pm 5.8$. ${ }^{*} p<0.05$ compared with wtIL6Luc stimulated with $45 \mathrm{~mm} \mathrm{KCl}$. $C$, Cerebellar granule cells were transfected with reporter gene constructs containing either the wild-type IL-6 promoter or the IL-6 promoter with a mutation in the GRE2. ${ }^{*} p<0.05$ compared with the untreated control. $D$, Mutation of the GRE2 had no effect on IL-6 gene transcription in primary astrocytes that were stimulated by mobilization of intracellular $\mathrm{Ca}^{2+}$ with $1 \mu \mathrm{M}$ thapsigargin. Controls and stimulated cells were treated with $333 \mathrm{~nm} 12-O$-tetradecanoylphorbol-13-acetate. Data are mean \pm SEM values of at least three independent experiments, each done in duplicate.

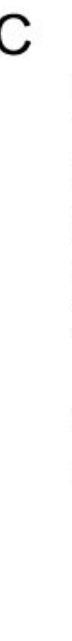

and the subsequent activation of CaM-dependent protein kinases is a well known cascade in neuronal gene regulation. This cascade was first described in the case of depolarization-induced c-fos gene transcription (Ghosh and Greenberg, 1995) and has since been confirmed for several other genes that are induced by membrane depolarization (Kilbourne et al., 1992; Schwaninger et al., 1993a). The IL-6 promoter binds at least two transcription factors, cAMP response element-binding protein and NF-IL6, which are activated by CaM kinases in other contexts (Ghosh and Greenberg, 1995). Another $\mathrm{Ca}^{2+}$-responsive regulator of IL-6 gene transcription is NF- $\kappa$ B (Dolmetsch et al., 1997). Surprisingly, none of these factors seems to be responsible for the effect of membrane depolarization and $\mathrm{Ca}^{2+}$ influx on IL- 6 gene transcription. Instead, the mutational analysis of the IL- 6 promoter showed the GRE2 as the $\mathrm{Ca}^{2+}$ response element in neurons.

The GRE2 in the IL- 6 promoter has been defined according to a sequence homology to consensus GREs and is conserved in humans and mice (Tanabe et al., 1988). To date, its function has not been analyzed. Although the GRE2 was able to bind the GR and mediated an induction of gene transcription by dexamethasone, the binding of the GR does not seem to be responsible for the effect of membrane depolarization. In fact, gel shift assays demon-
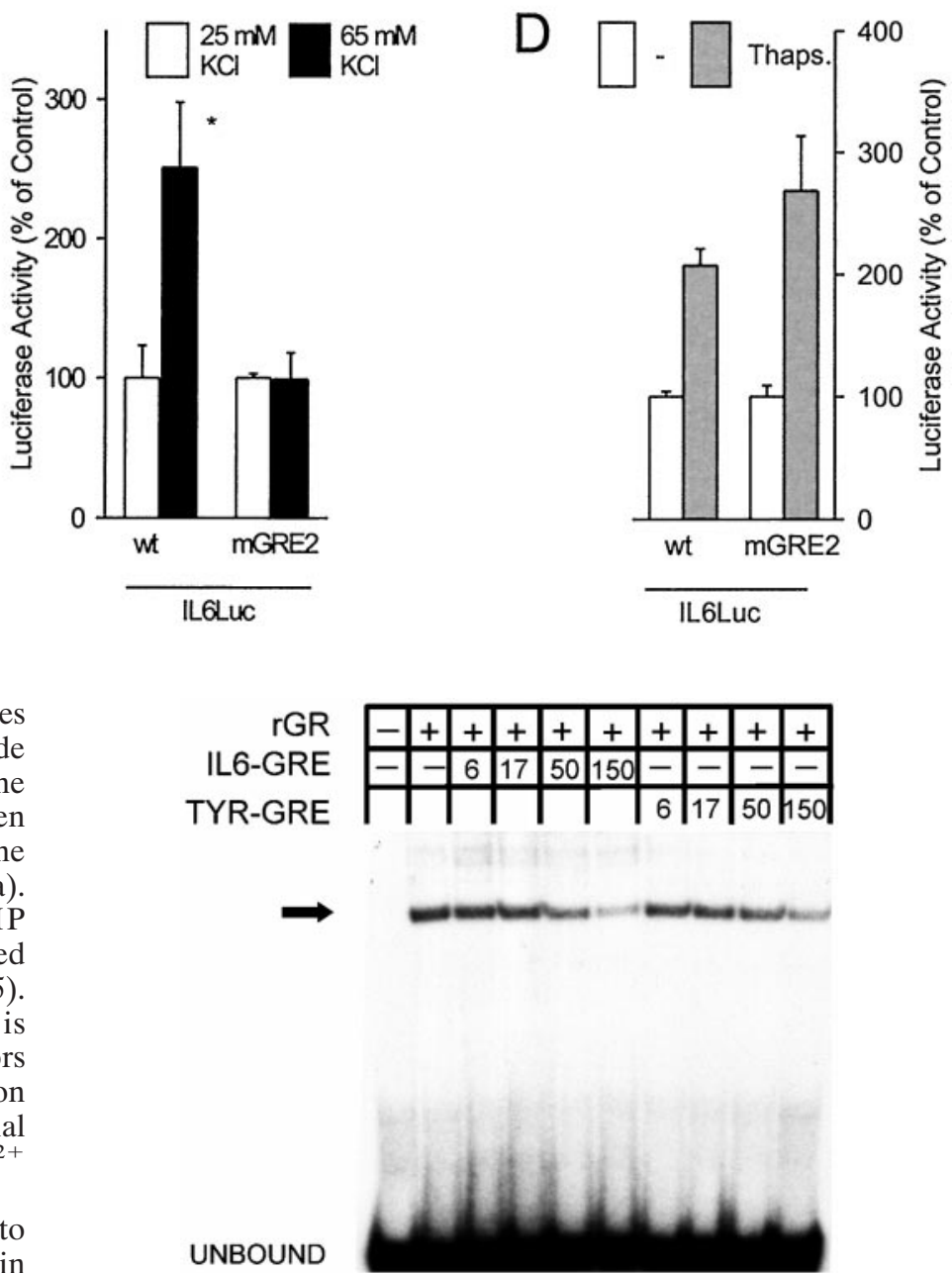

Figure 4. rGR binds to the IL-6 GRE2. In gel shift assays, the labeled IL-6 GRE2 was incubated with rGR. Increasing concentrations of the IL-6 GRE2 or a typical GRE from the tyrosine aminotransferase promoter competed for binding. The fold excess of competitors over the labeled probe is given in the legend. 
$5 \mathrm{mM} \mathrm{KCl}$

$45 \mathrm{mM} \mathrm{KCl}$

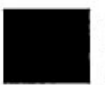

Dexa-

methasone

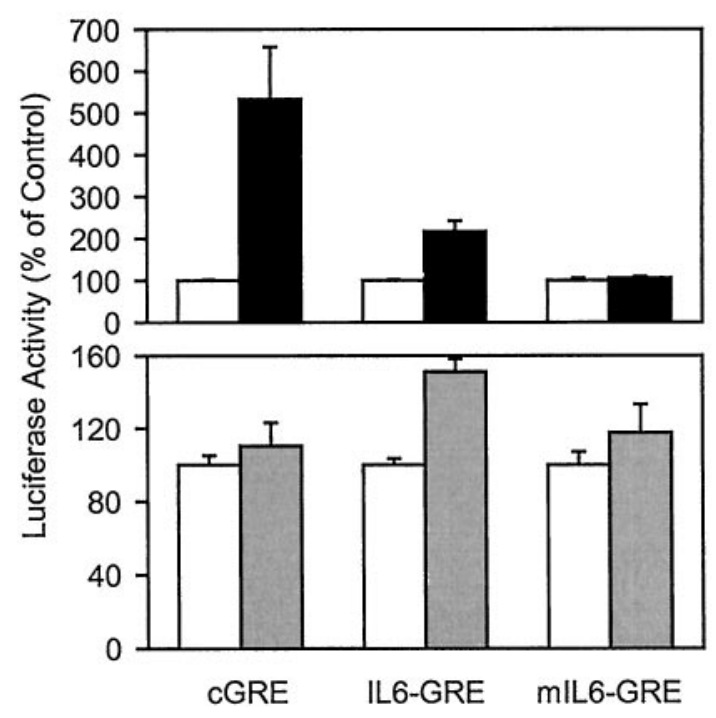

Figure 5. Stimulation of GRE-directed transcription by dexamethasone and membrane depolarization can be dissociated in PC-12 cells. Whereas the IL-6 GRE2 responds to both dexamethasone and membrane depolarization, a consensus GRE was only stimulated by dexamethasone. Data are mean \pm SEM values of three independent experiments, each done in duplicate.

\begin{tabular}{|c|c|c|c|c|c|c|c|c|c|}
\hline Comp & - & & & $\kappa$ & & $\overline{G R}$ & & & \\
\hline $\mathrm{NE}$ & & $U$ & $D$ & $\mathrm{U}$ & $D$ & $\mathrm{u}$ & $D$ & & D \\
\hline
\end{tabular}

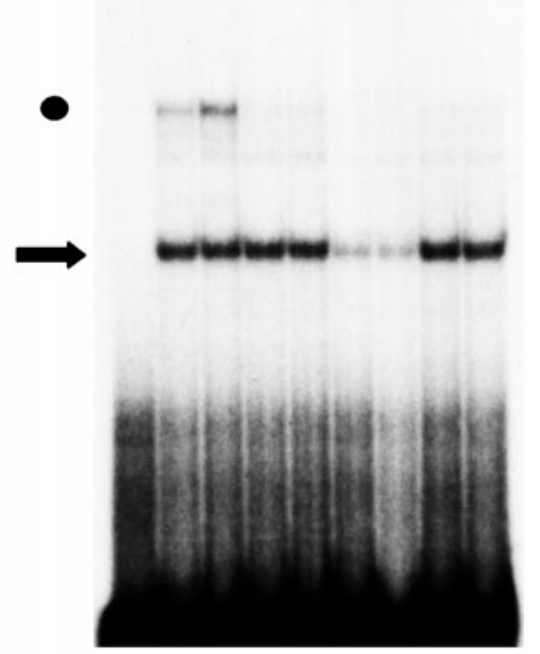

Figure 6. In gel shift assays of nuclear extracts $(N E)$ from PC-12 cells, a complex was found that bound in a sequence-specific manner to the IL-6 GRE2 (arrow) as it was reduced by a 300-fold excess of wild-type IL-6 GRE2 but not by a mutated or an unrelated oligonucleotide as competitors (Comp). Treatment of PC-12 cells with $10 \mu \mathrm{M}$ dexamethasone $(D)$ did not influence the binding. Dot indicates unspecific binding. $U, \mathrm{PC}-12$ cells were untreated.

strated a different factor binding close to the GR. This factor is a candidate for mediating the $\mathrm{Ca}^{2+}$ responsiveness because its binding to the GRE2 showed the same mutational sensitivity as the $\mathrm{Ca}^{2+}$ responsiveness. Furthermore, it may displace the GR from its binding site and thereby restrict the effect of glucocorticoids on GRE2-directed gene transcription, which could explain why the overall effect of glucocorticoids on IL-6 gene transcription is inhibitory (Ray et al., 1990). The identity of this factor is unknown.

The induction of IL- 6 gene transcription by membrane depolarization and $\mathrm{Ca}^{2+}$ influx may explain the increased expression of IL-6 after epileptic seizures that we and others have observed (de Bock et al., 1996; Rosell et al., 1999). Moreover, it may underlie the increased expression of IL-6 after in vivo administration of excitatory amino acids (Minami et al., 1991; Schiefer et al., 1998) and the upregulation of IL- 6 in neurons of the contralateral hemisphere after focal cerebral ischemia, a pattern that closely resembles spreading depression (Suzuki et al., 1999b). Both peripheral and central neurons express IL-6 also after axotomy (Murphy et al., 1995; Hans et al., 1999). In many paradigms, axotomy is accompanied by a transient membrane depolarization and elevation of intracellular $\mathrm{Ca}^{2+}$ concentrations and by a prolonged increase in excitability (Berdan et al., 1993; Ziv and Spira, 1993; Zhang et al., 1997). In the case of large neurons of dorsal root ganglia, an increase in neuronal activity may partially contribute to the induction of IL- 6 after axotomy, although other causes are suggested by the fact that a more distal site of axotomy decreases the excitability but increases IL-6 expression (Murphy et al., 1995, 1999; Liu et al., 2000). Moreover, induction of IL-6 by membrane depolarization suggests a mechanism through which IL-6 may be regulated under normal, physiological conditions in neurons. Recently, cytokines have been implicated as neuromodulators in normal brain function (Vitkovic et al., 2000). Evidence of altered emotional behavior in IL-6-deficient mice supports such a role of IL-6 (Armario et al., 1998; Butterweck et al., 2000). IL-6 released from neurons may exert its modulatory effects on behavior by altering receptormediated membrane responses and inhibiting long-term potentiation (Li et al., 1997; Qiu et al., 1998; Xia et al., 1999). In neurological diseases, IL-6 may function like BDNF as a depolarizationinduced neuroprotective factor (Ghosh et al., 1994; Zhong et al., 1999). The induction of an important immune mediator, such as IL-6, by neuronal activity may, furthermore, provide a molecular mechanism in the brain to control immune functions.

\section{REFERENCES}

Amano Y, Lee SW, Allison AC (1993) Inhibition by glucocorticoids of the formation of interleukin-1 alpha, interleukin-1 beta, and interleukin-6: mediation by decreased mRNA stability. Mol Pharmacol 43:176-182.

Ango F, Albani-Torregrossa S, Joly C, Robbe D, Michel JM, Pin JP, Bockaert J, Fagni L (1999) A simple method to transfer plasmid DNA into neuronal primary cultures: functional expression of the mGlu5 receptor in cerebellar granule cells. Neuropharmacology 38:793-803.

Armario A, Hernandez J, Bluethmann H, Hidalgo J (1998) IL-6 deficiency leads to increased emotionality in mice: evidence in transgenic mice carrying a null mutation for IL-6. J Neuroimmunol 92:160-169.

Benveniste EN (1992) Inflammatory cytokines within the central nervous system: sources, function, and mechanism of action. Am J Physiol 263:C1-C16.

Berdan RC, Easaw JC, Wang R (1993) Alterations in membrane potential after axotomy at different distances from the soma of an identified neuron and the effect of depolarization on neurite outgrowth and calcium channel expression. J Neurophysiol 69:151-164.

Bost KL, Mason MJ (1995) Thapsigargin and cyclopiazonic acid initiate rapid and dramatic increases of IL-6 mRNA expression and IL-6 secretion in murine peritoneal macrophages. J Immunol 155:285-296.

Burd PR, Rogers HW, Gordon JR, Martin CA, Jayaraman S, Wilson SD, Dvorak AM, Galli SJ, Dorf ME (1989) Interleukin 3-dependent and -independent mast cells stimulated with IgE and antigen express multiple cytokines. J Exp Med 170:245-257.

Butterweck V, Prinz S, Schwaninger M (2000) The role of interleukin-6 in stress-induced hyperthermia and emotional behaviour in mice. Naunyn Schmiedebergs Arch Pharmacol [Suppl 4] 361:R103.

Campbell IL, Abraham CR, Masliah E, Kemper P, Inglis JD, Oldstone MB, Mucke L (1993) Neurologic disease induced in transgenic mice by cerebral overexpression of interleukin 6. Proc Natl Acad Sci USA 90:10061-10065.

Chai Z, Gatti S, Toniatti C, Poli V, Bartfai T (1996) Interleukin (IL)-6 gene expression in the central nervous system is necessary for fever response to lipopolysaccharide or IL-1 $\beta$ : a study on IL-6-deficient mice. J Exp Med 183:311-316.

de Bock F, Dornand J, Rondouin G (1996) Release of TNF $\alpha$ in the rat hippocampus following epileptic seizures and excitotoxic neuronal damage. NeuroReport 7:1125-1129.

Dolmetsch RE, Lewis RS, Goodnow CC, Healy JI (1997) Differential 
activation of transcription factors induced by $\mathrm{Ca}^{2+}$ reponse amplitude and duration. Nature 368:855-858.

Fattori E, Lazzaro D, Musiani P, Modesti A, Alonzi T, Ciliberto G (1995) IL-6 expression in neurons of transgenic mice causes reactive astrocytosis and increase in ramified microglial cells but no neuronal damage. Eur J Neurosci 7:2441-2449.

Frantz B, Nordby EC, Bren G, Steffan N, Paya CV, Kincaid RL, Tocci MJ, O'Keefe SJ, O'Neill EA (1994) Calcineurin acts in synergy with PMA to inactivate $\mathrm{I} \kappa \mathrm{B} / \mathrm{MAD} 3$, an inhibitor of NF- $\kappa \mathrm{B}$. EMBO J 13:861-870.

Frei K, Malipiero UV, Leist TP, Zinkernagel RM, Schwab ME, Fontana A (1989) On the cellular source and function of interleukin 6 produced in the central nervous system in viral disease. Eur J Immunol 19:689-694

Gadient RA, Otten U (1994) Identification of interleukin-6 (IL-6)expressing neurons in the cerebellum and hippocampus of normal adult rats. Neurosci Lett 182:243-246.

Gadient RA, Otten UH (1997) Interleukin-6 (IL-6) - a molecule with both beneficial and destructive potentials. Prog Neurobiol 52:379-390.

Gauldie J, Richards C, Harnish D, Lansdorp P, Baumann H (1987) Interferon beta2/B-cell stimulating factor type 2 shares identity with monocyte-derived hepatocyte-stimulating factor and regulates the acute phase response in liver cells. Proc Natl Acad Sci USA 84:7251-7259.

Ghosh A, Greenberg ME (1995) Calcium signaling in neurons: molecular mechanisms and cellular consequences. Science 268:239-247.

Ghosh A, Carnahan J, Greenberg ME (1994) Requirement for BDNF in activity-dependent survival of cortical neurons. Science 263:1618-1623.

Goodman MN (1994) Interleukin-6 induces skeletal muscle breakdown in rats. Proc Soc Exp Biol Med 205:182-185.

Hama T, Kushima Y, Miyamoto M, Kubota M, Takei N, Hatanaka H (1991) Interleukin-6 improves the survival of mesencephalic catecholaminergic and septal cholinergic neurons from postnatal, two-weekold rats in cultures. Neuroscience 40:445-452.

Hans VHJ, Kossmann T, Lenzlinger PM, Probstmeier R, Imhof H-G, Trentz O, Morganti-Kossmann MC (1999) Experimental axonal injury triggers interleukin-6 mRNA, protein synthesis and release into cerebrospinal fluid. J Cereb Blood Flow Metab 19:184-194.

Kilbourne EJ, Nankova BB, Lewis EJ, McMahon A, Osaka H, Sabban DB, Sabban EL (1992) Regulated expression of the tyrosine hydroxylase gene by membrane depolarization. J Biol Chem 267:7563-7569.

Klein MA, Möller JC, Jones LL, Bluethmann H, Kreutzberg GW, Raivich $\mathrm{G}$ (1997) Impaired neuroglial activation in interleukin-6 deficient mice. Glia 19:227-233.

Kopf M, Baumann H, Freer G, Freudenberg M, Lamers M, Kishimoto T, Zinkernagel R, Bluethmann H, Kohler G (1994) Impaired immune and acute phase responses in interleukin-6 deficient mice. Nature 368:339-342.

Kozak W, Poli V, Soszynski D, Conn CA, Leon LR, Kluger MJ (1997) Sickness behavior in mice deficient in interleukin-6 during turpentine abscess and influenza pneumonitis. Am J Physiol 272:R621-R630.

Li AJ, Katafuchi T, Oda S, Hori T, Oomura Y (1997) Interleukin-6 inhibits long-term potentiation in rat hippocampal slices. Brain Res 748:30-38.

Liu CN, Wall PD, Ben-Dor E, Michaelis M, Amir R, Devor M (2000) Tactile allodynia in the absence of $\mathrm{C}$-fiber activation: altered firing properties of DRG neurons following spinal nerve injury. Pain 85:503-521.

Loddick SA, Turnbull AV, Rothwell NJ (1998) Cerebral Interleukin-6 is neuroprotective during permanent focal cerebral ischemia in the rat. J Cereb Blood Flow Metab 18:176-179.

März P, Cheng JG, Gadient RA, Patterson PH, Stoyan T, Otten U, Rose-John S (1998) Sympathetic neurons can produce and respond to interleukin 6. Proc Natl Acad Sci USA 95:3251-3256.

Matsuda S, Wen TC, Morita F, Otsuka H, Igase K, Yoshimura H, Sakanaka M (1996) Interleukin-6 prevents ischemia-induced learning disabilities and neuronal and synaptic loss in gerbils. Neurosci Lett 204:109-112.

Minami M, Kuraishi Y, Satoh M (1991) Effects of kainic acid on messenger RNA levels of IL-1 $\beta$, IL-6, TNF $\alpha$ and LIF in the rat brain. Biochem Biophys Res Commun 176:593-598.

Murphy PG, Grondin J, Altares M, Richardson PM (1995) Induction of interleukin-6 in axotomized sensory neurons. J Neurosci 15:5130-5138.

Murphy PG, Borthwick LS, Johnston RS, Kuchel G, Richardson PM (1999) Nature of the retrograde signal from injured nerves that induces interleukin-6 mRNA in neurons. J Neurosci 19:3791-3800.

Nordeen GP (1988) Luciferase reporter gene vectors for analysis of promoters and enhancers. Biotechniques 6:454-457.

Qiu Z, Sweeney DD, Netzeband JG, Gruol DL (1998) Chronic interleukin-6 alters NMDA receptor-mediated membrane responses and enhances neurotoxicity in developing CNS neurons. J Neurosci 18:10445-10456.

Ray A, LaForge KS, Sehgal PB (1990) On the mechanism for efficient repression of the interleukin-6 promoter by glucocorticoids: enhancer, TATA box, and RNA start site (Inr motif) occlusion. Mol Cell Biol 10:5736-5746.

Ringheim GE, Burgher KL, Heroux JA (1995) Interleukin-6 mRNA expression by cortical neurons in culture: evidence for neuronal sources of interleukin-6 production in the brain. J Neuroimmunol 63:113-123.

Rosell DR, Nacher HM, Chao HM, McEwen BS (1999) Interleukin-6 expression in the rat hippocampus in response to excitotoxic injury. Soc Neurosci Abstr 25:610-611.

Rozansky DJ, Wu H, Tang K, Parmer RJ, O’Connor DT (1994) Glucocorticoid activation of chromogranin A gene expression. Identification and characterization of a novel glucocorticoid response element. J Clin Invest 94:2357-2368.

Ruzek MC, Miller AH, Opal SM, Pearce BD, Biron CA (1997) Characterization of early cytokine responses and an interleukin (IL)-6dependent pathway of endogenous glucocorticoid induction during murine cytomegalovirus infection. J Exp Med 185:1185-1192.

Schiefer J, Töpper R, Schmidt W, Block F, Heinrich PC, Noth J, Schwarz M (1998) Expression of interleukin 6 in the rat striatum following stereotaxic injection of quinolinic acid. J Neuroimmunol 89:168-176.

Schöbitz B, de K-ER, Sutanto W, Holsboer F (1993) Cellular localization of interleukin 6 mRNA and interleukin 6 receptor mRNA in rat brain. Eur J Neurosci 5:1426-1435.

Schreiber E, Matthias P, Müller MM, Schaffner W (1989) Rapid detection of octamer binding proteins with "mini-extracts," prepared from small number of cells. Nucleic Acids Res 17:6419.

Schwaninger M, Lux G, Blume R, Oetjen E, Hidaka H, Knepel W (1993a) Membrane depolarization and calcium influx induce glucagon gene transcription in pancreatic islet cells through the cyclic AMP-responsive element. J Biol Chem 268:5168-5177.

Schwaninger M, Blume R, Oetjen E, Lux G, Knepel W (1993b) Inhibition of cAMP-responsive element-mediated gene transcription by cyclosporin A and FK 506 after membrane depolarization. J Biol Chem 268:23111-23115.

Schwaninger M, Neher M, Viegas E, Schneider A, Spranger M (1997) Stimulation of interleukin-6 secretion and gene transcription in primary astrocytes by adenosine. J Neurochem 69:1145-1150.

Schwaninger M, Sallmann S, Schneider A, Prinz S, Liberman TA, Hacke W, Spranger M (1999) Bradykinin induces interleukin 6 expression in astrocytes through activation of NF- $\kappa$ B. J Neurochem 73:1461-1466.

Sehgal PB (1992) Regulation of IL6 gene expression. Res Immunol 143:724-734.

Sheng M, McFadden G, Greenberg ME (1990) Membrane depolarization and calcium induce c-fos transcription via phosphorylation of transcription factor CREB. Neuron 4:571-582.

Suzuki S, Tanaka K, Nagata E, Ito D, Dembo T, Fukuuchi Y (1999a) Cerebral neurons express interleukin-6 after transient forebrain ischemia in gerbils. Neurosci Lett 262:117-120.

Suzuki S, Tanaka K, Nogawa S, Nagata E, Ito D, Dembo T, Fukuuchi Y (1999b) Temporal profile and cellular localization of interleukin-6 protein after focal cerebral ischemia in rats. J Cereb Blood Flow Metab 19:1256-1262

Tanabe O, Akira S, Kamiya T, Wong GG, Hirano T, Kishimoto T (1988) Genomic structure of the murine IL-6 gene. High degree conservation of potential regulatory sequences between mouse and human. J Immunol 141:3875-3881.

Toman JEP, Swinyard E, Goodman LS (1946) Properties of maximal seizures, and their alteration by anticonvulsant drugs and other agents. J Neurophysiol 9:231-239.

Vitkovic L, Bockaert J, Jacque C (2000) “Inflammatory" cytokines: neuromodulators in normal brain? J Neurochem 74:457-471.

Wegner M, Cao Z, Rosenfeld MG (1992) Calcium-regulated phosphorylation within the leucin zipper of C/EBP $\beta$. Science 256:370-373.

Xia Y, Hu H-Z, Liu S, Ren J, Zafirov DH, Wood JD (1999) IL-1 $\beta$ and IL-6 excite neurons and suppress nicotinic and noradrenergic neurotransmission in guinea pig enteric nervous system. J Clin Invest 103:1309-1316.

Yamada M, Hatanaka H (1994) Interleukin-6 protects cultured rat hippocampal neurons against glutamate-induced cell death. Brain Res 643:173-180.

Zhang J-M, Donnelly DF, Song X-J, LaMotte RH (1997) Axotomy increases the excitability of dorsal root ganglion cells with unmyelinated axons. J Neurophysiol 78:2790-2794.

Zhong J, Dietzel ID, Wahle P, Kopf M, Heumann R (1999) Sensory impairment and delayed regeneration of sensory axons in interleukin-6deficient mice. J Neurosci 19:4305-4313.

Ziv NE, Spira ME (1993) Spatiotemporal distribution of $\mathrm{Ca}^{2+}$ following axotomy and throughout the recovery process of cultured Aplysia neurons. Eur J Neurosci 5:657-668. 